\title{
Article \\ Comparison of the Radial Growth Response of Picea crassifolia to Climate Change in Different Regions of the Central and Eastern Qilian Mountains
}

\author{
Xuan Wu, Liang Jiao*(D), Dashi Du, Changliang Qi and Ruhong Xue \\ College of Geography and Environment Science, Northwest Normal University, No. 967, Anning East Road, \\ Lanzhou 730070, China; 15002550410@163.com (X.W.); dashidu@163.com (D.D.); \\ sd2019212378@163.com (C.Q.); xrhnwnu@163.com (R.X.) \\ * Correspondence: jiaoliang@nwnu.edu.cn; Tel.: +86-139-1935-0195
}

check for updates

Citation: Wu, X.; Jiao, L.; Du, D.; Qi, C.; Xue, R. Comparison of the Radial Growth Response of Picea crassifolia to Climate Change in Different Regions of the Central and Eastern Qilian Mountains. Forests 2021, 12, 1015. https://doi.org/10.3390/f12081015

Academic Editor: Keryn Paul

Received: 26 June 2021

Accepted: 28 July 2021

Published: 30 July 2021

Publisher's Note: MDPI stays neutral with regard to jurisdictional claims in published maps and institutional affiliations.

Copyright: (c) 2021 by the authors. Licensee MDPI, Basel, Switzerland. This article is an open access article distributed under the terms and conditions of the Creative Commons Attribution (CC BY) license (https:/ / creativecommons.org/licenses/by/ $4.0 /)$.

\begin{abstract}
It is important to explore the responses of radial tree growth in different regions to understand growth patterns and to enhance forest management and protection with climate change. We constructed tree ring width chronologies of Picea crassifolia from different regions of the Qilian Mountains of northwest China. We used Pearson correlation and moving correlation to analyze the main climate factors limiting radial growth of trees and the temporal stability of the growth-climate relationship, while spatial correlation is the result of further testing the first two terms in space. The conclusions were as follows: (1) Radial growth had different trends, showing an increasing followed by a decreasing trend in the central region, a continuously increasing trend in the eastern region, and a gradually decreasing trend in the isolated mountain. (2) Radial tree growth in the central region and isolated mountains was constrained by drought stress, and tree growth in the central region was significantly negatively correlated with growing season temperature. Isolated mountains showed a significant negative correlation with mean minimum of growing season and a significant positive correlation with total precipitation. (3) Temporal dynamic responses of radial growth in the central region to the temperatures and SPEI (the standardized precipitation evapotranspiration index) in the growing season were unstable, the isolated mountains to total precipitation was unstable, and that to SPEI was stable. The results of this study suggest that scientific management and maintenance plans of the forest ecosystem should be developed according to the response and growth patterns of the Qinghai spruce to climate change in different regions of the Qilian Mountains.
\end{abstract}

Keywords: divergent response; climate change; Qilian Mountains; Qinghai spruce; drought stress

\section{Introduction}

Forest ecosystems cover about 30\% of the Earth's total land area [1]. As an important part of terrestrial ecosystems, they play a key role in maintaining the global carbon balance, regulating the terrestrial water cycle, conserving soil and water, and preserving the environment [2,3]. At present, global warming has become an indisputable fact. The annual mean temperature of the northern hemisphere of the last 30 years is the hottest it has been in the past 800 to 1400 years [4]. It is estimated that the global average surface temperature will rise by 1.4 to $5.8^{\circ} \mathrm{C}$ by 2100 [5]. Climate change has profoundly affected tree growth, phenology, species composition, and distribution in forest ecosystems.

Tree ring records are a reliable indicator of climate effects that have been used to explore the ability of forest ecosystems to adapt to climate change. At the same time, dendroclimatology has been used to assess tree growth-climate relationships to provide a basis for climate change studies [6]. Traditional dendrochronology assumes a quasilinear response of tree rings to climatic variables, with a stable relationship between tree growth and limiting climate factors over time, which has generally been proposed as the "uniformitarian principle" [7]. This regression function with the approximate linear 
relationship has been widely used for climate reconstruction-based tree ring data. However, this principle has been challenged by numerous studies over the past few decades [8]. In particular, the "divergence problem" is characterized by a complex nonlinear relationship between the growth of trees and climate variables, namely, the reduction, increase, or loss in sensitivity to climate factors. For example, unstable responses to climate factors were observed in Larix sibirica in the eastern Tianshan Mountains [9], Quercus mongolica and Pinus koraiensis in northeast China [10], Quercus robur in the United Kingdom [11], and Abies faxoniana in the Balang Mountains in China's Western Sichuan Province [12]. However, Larix decidua in the European Alps [13] and Picea abies, Pinus sylvestris [3], and Quercus petraea [14] in the middle latitudes of northwest China showed relatively stable responses to limiting climatic factors. Therefore, the "divergence problem" remains uncertain.

Studies have found numerous complications in the growth patterns of trees in the context of climate change. For example, the growth trends of Larix gmelinii in the Kamchatka Peninsula [15], Pinus nigra in the Iberian [16], and Betula ermanii in Japan showed increased radial growth due to a warming climate [17]. In contrast, the growth trends of Buxus sinica in West Virginia showed a sharp decline [18]. At the same time, there are many differences in terms of response to climate. For example, the response of B. ermanii to temperature varies with different elevation [17], and P. sylvestris in Switzerland has different responses to summer and winter temperatures [19]. Tree species of different ages in Patagonia's arid region respond differently to drought, where Acer velutinum is the most sensitive to precipitation in August, but its response to temperature is not obvious [20]. Thus, there are uncertainties involved in the growth response patterns of forest ecosystems to climate change, and more research is needed on a broader scale.

Moreover, the same plant distributed in different environments has the characteristics of divergent adaptation, which means that it develops different morphological, physiological, and behavioral characteristics in response to heterogeneous environments. For example, decreasing growth trends of Fagus sylvatic have been observed in Spain, Italy, and Hungary due to warming and drying [21,22]. At the same time, increased trends of growth have been detected in Romania [23]. Likewise, most Abies alba populations located in Spain and southern Italy have displayed a marked decline in growth in recent decades. However, an increasing trend of growth has been observed in northern Italy and Romania over the last two decades [15]. These variations are caused by the long-term effects of different environmental conditions. Therefore, the effects of climate change on tree growth are not uniform due to spatial heterogeneity and variability among populations [24]. At present, there are few studies on the dynamic comparison of the growth-climate relationship and growth patterns of the same tree species in different regions due to climate change. Therefore, it is important to strengthen such studies for us to explore the growth strategies of the same tree species in different forest systems.

The Qilian Mountains are located in a transition zone between the Tibetan Plateau, the eastern monsoon region, and the northwestern arid region of China, which is affected by the interaction of westerly and East Asian monsoons [25]. As the main species of the forest system in the Qilian Mountains, the Qinghai spruce plays an important role in water conservation and carbon sequestration [26,27]. A study of Qinghai spruce in this region showed that the stability of tree response to climate factors is used to reconstruct various meteorological indicators. For example, PDSI (the Palmer Drought Severity Index) [28], annual precipitation [29], and temperature [30] in the Qilian Mountains were reconstructed using the tree-wheel width chronology of the Qinghai spruce. In addition, the growth pattern of trees in the Qilian Mountains is complex. For example, a significant decline in the radial growth of Qinghai spruce in recent decades has been detected in the Midwestern region of the Qilian Mountains [31]. The Pinus tabuliformis decreased significantly after the temperature abruptly increased in the Qilian Mountains [32]. At present, studies on the relationship between tree growth and climate have mostly been concentrated in the central and western regions of the Qilian Mountains. However, we know little about the comparative study of tree growth in the central and eastern regions of the Qilian 
Mountains. According to the research, while the Qinghai spruce has experienced radial growth inhibition due to climate warming [33], it has also experienced an increase in growth in recent years [34]. Such inconsistent results affect our understanding of the response of Qinghai spruce growth to climate change, so it is necessary to study the growth trends of trees under warming conditions and their causes, and assess their growth dynamics in a timely fashion in different regions. Therefore, we constructed the tree ring width chronologies of the Qinghai spruce in the central, eastern, and isolated mountain regions of the Qilian Mountains, to (1) compare the difference of growth patterns of Qinghai spruce, (2) determine the main climate factors affecting the growth of Qinghai spruce and their response stability, and (3) predict the future growth trends of the Qinghai spruce. We hypothesized that forests in all three regions are affected by high-temperature-induced drought stress, especially in the drier central region and isolated mountains.

\section{Materials and Methods}

\subsection{Study Area}

The study area is located in the central and eastern Qilian Mountains of northwest China (Figure 1). The climate is temperate, continental, and arid, with little rainfall and large temperature differences. The Qinghai spruce is one of the dominant tree species in the Qilian Mountains, and is mainly distributed on shady and semi-shady slopes above $2350 \mathrm{~m}$ in elevation [35]. According to the meteorological data, the annual mean maximum, mean, and mean minimum temperatures in the central region of the Qilian Mountains from 1957 to 2018 were $2.2,-4.2$, and $-10.7^{\circ} \mathrm{C}$, respectively. The increase was 0.12 , 0.16 , and $0.14{ }^{\circ} \mathrm{C} / 10$ a respectively, and the annual total precipitation was $170.4 \mathrm{~mm}$ with an increasing trend of $6.01 \mathrm{~mm} / 10 \mathrm{a}$. The annual mean maximum, mean, and mean minimum temperatures in the eastern region were $8.9,3.1$, and $-2.7^{\circ} \mathrm{C}$, with increases of $0.12,0.18$, and $0.15^{\circ} \mathrm{C} / 10 \mathrm{a}$, respectively. The annual total precipitation was $329.4 \mathrm{~mm}$, with an increasing trend of $4.15 \mathrm{~mm} / 10 \mathrm{a}$. The annual mean maximum, mean, and mean minimum temperatures in the isolated mountains were $9.7,4.0$, and $-10.7^{\circ} \mathrm{C}$, representing an increasing trend of $0.12,0.22$, and $0.17^{\circ} \mathrm{C} / 10$ a, respectively (Figure 2). The annual total precipitation was $280.0 \mathrm{~mm}$, with an increasing trend of $2.9 \mathrm{~mm} / 10$ a. The monthly maximum values of the four meteorological indicators were all concentrated in JuneAugust, which is the growing season stage of the Qinghai spruce (Figure 3).
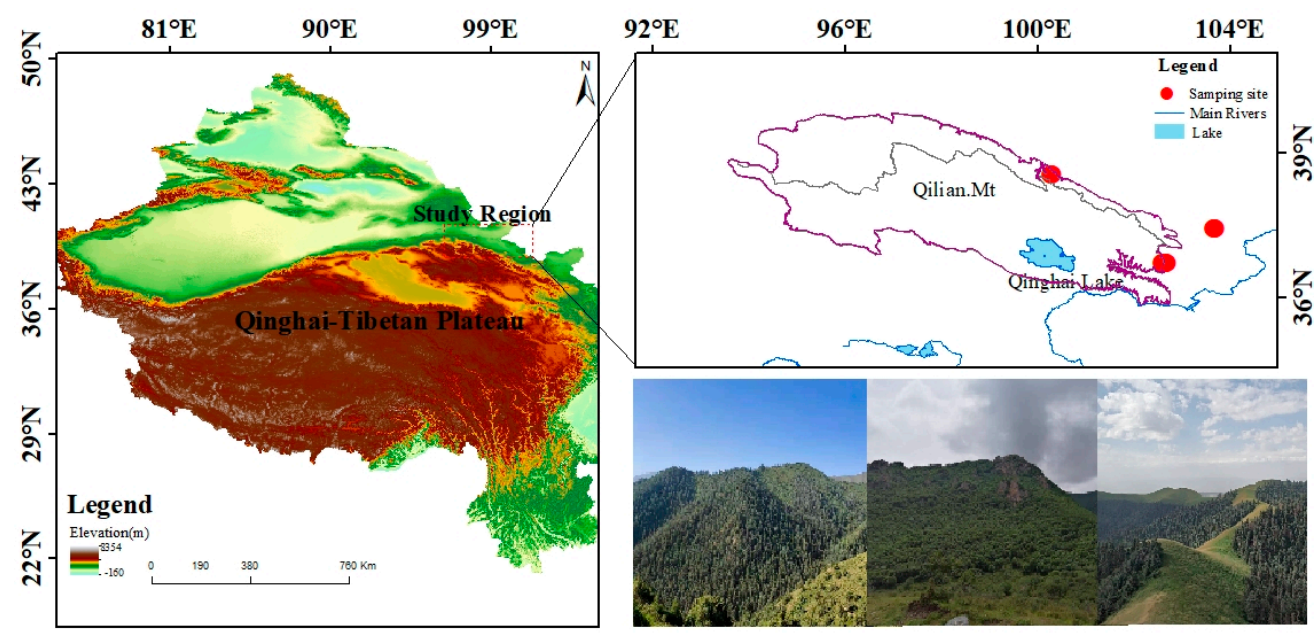

Figure 1. Locations of the sampling sites. 


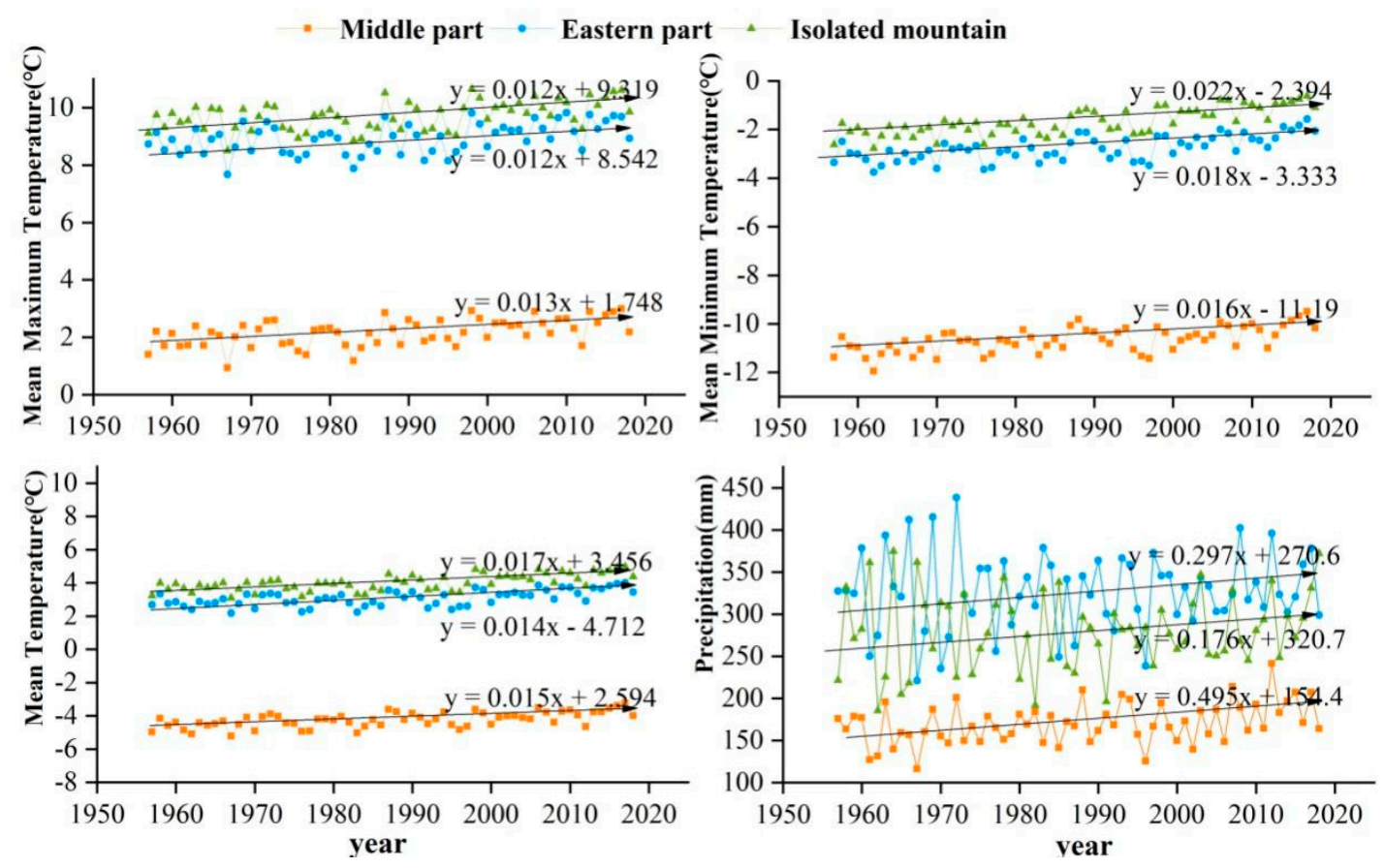

Figure 2. Interannual variabilities of the mean maximum, mean minimum, mean temperatures, and total precipitation for 1957-2018 in three Central and Eastern Qilian Mountains regions.

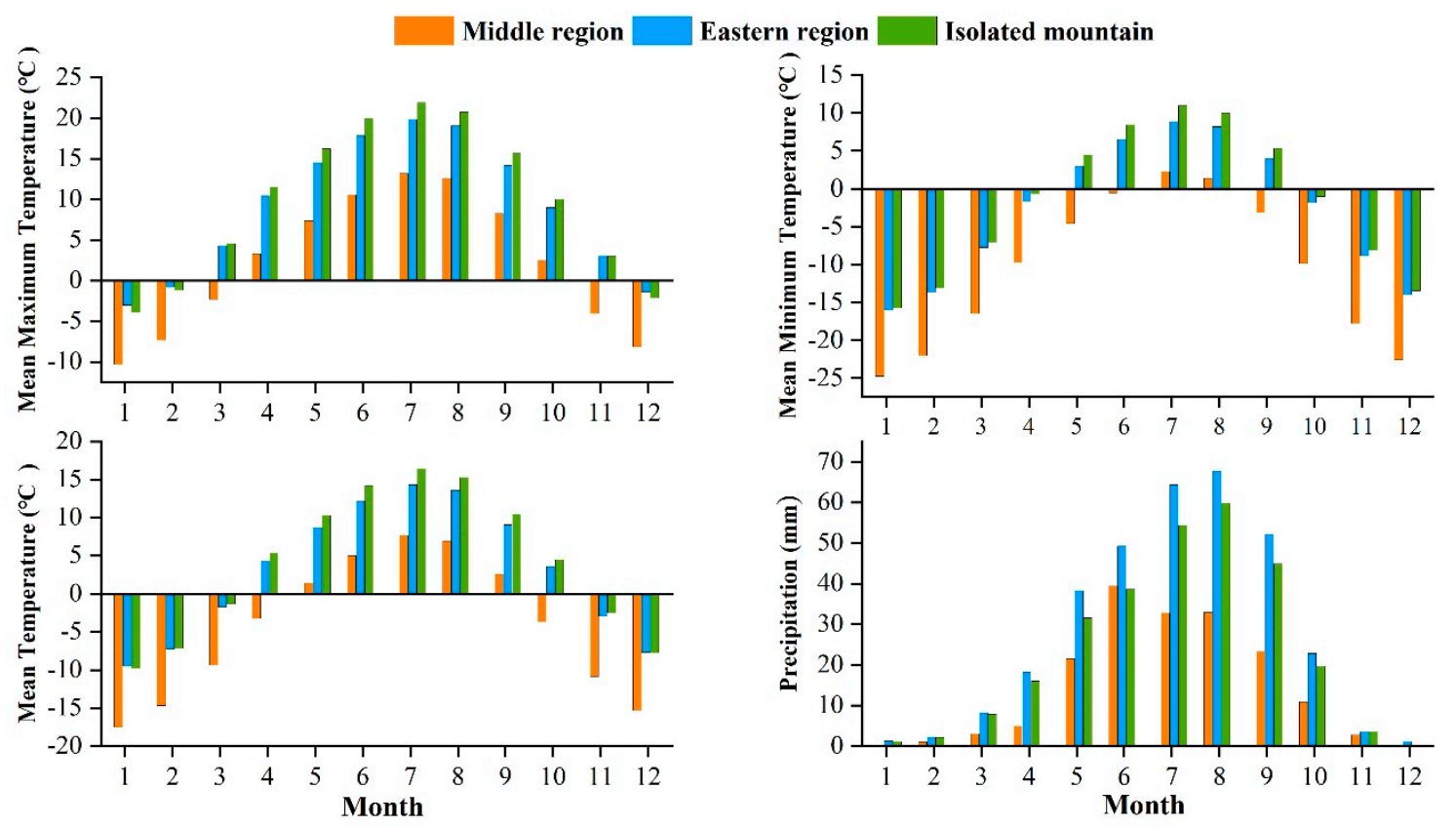

Figure 3. Monthly mean maximum, mean minimum, mean temperatures, and total precipitation, during 1957-2018 in the three Central and Eastern Qilian Mountains regions.

\subsection{Methods}

To test the growth-climate relationship, we calculated the Pearson correlation coefficients between tree-ring width chronologies of the trees in three regions during 1957-2018. Additionally, we accurately depicted the growth-climate temporal relationship with a moving correlation function using DendroClim 2002 [36]. We employed a fixed 30-year period starting from 1957 that slid across time to compute the correlation coefficients between tree-ring and climate factors in tree regions. Finally, we also calculated the spatial Pearson 
correlation with the Climate Explorer website (http:/ / climexp.knmi.nl/, accessed on 26 February 2020) to estimate the stability of radial growth responses and test the accuracy of the moving correlation results. Spatial Pearson correlations reflect large-scale response patterns, driving the radial growth of trees.

\subsection{Meteorological Data}

Meteorological data were extracted from the CRUTS4.04 climate data grid for the period 1957 to 2018. Both are from the Royal Netherlands Meteorological Institute (http:/ / climexp.knmi.nl/, accessed on 26 February 2020) with a resolution of $0.5^{\circ} \times 0.5^{\circ}$, including mean maximum temperature, mean minimum temperature, mean temperature, and total precipitation. In addition, SPEI data were calculated using climate data (precipitation, temperature, relative humidity, solar radiation, water vapor pressure, and wind speed) for the analysis of the responses of radial growth to drought and the evaluation of the effects of drought at different time scales on the radial growth of trees [37]. We also analyzed the relationships between the radial growth and SPEI data. Meanwhile, according to a large number of tree chronology studies and the "Lag effect" in tree physiology, tree growth is affected not only by the climatic conditions of that year, but also by the climate of the previous year [38]. Therefore, the monthly climate data from September of the previous year to October of that year are used in this study (Figure 3).

\subsection{Sample Collection}

The sampling points are located in the central, eastern, and isolated mountains of Qilian Mountain, with an altitude range of $2260-3300 \mathrm{~m}$ and a slope of $17^{\circ}-31.5^{\circ}$ (Table 1 ). In order to ensure the best data collected during the sampling process, healthy trees growing relatively sparse or without obvious physical damage caused by fire, disease, and pests were selected as samples. Along the direction parallel to or perpendicular to the direction of the mountain, a growth cone with a diameter of $5.15 \mathrm{~mm}$ was used to increment borer at the DBH of $1.3 \mathrm{~m}$ from the ground to extract tree cores. A total of 198 trees were investigated in July 2019 in three areas for a total of 386 cores.

Table 1. Information about the sampling sites of the Qinghai spruce.

\begin{tabular}{|c|c|c|c|c|c|c|c|}
\hline \multirow{2}{*}{$\begin{array}{c}\text { Regions } \\
\text { Sites }\end{array}$} & \multicolumn{3}{|c|}{ Central Region } & \multicolumn{2}{|c|}{ Eastern Region } & \multicolumn{2}{|c|}{ Isolated Mountain } \\
\hline & P1 & $\mathrm{P} 2$ & P3 & $\mathrm{P} 4$ & P5 & P6 & P7 \\
\hline Elevation (m) & 3300 & 2850 & 2585 & 2903 & 2260 & 2742 & 2562 \\
\hline Latitude $(\mathrm{N})$ & $38^{\circ} 32^{\prime} 8^{\prime \prime}$ & $38^{\circ} 33^{\prime} 9^{\prime \prime}$ & $38^{\circ} 36^{\prime} 49^{\prime \prime}$ & $36^{\circ} 42^{\prime} 35^{\prime \prime}$ & $36^{\circ} 43^{\prime} 11^{\prime \prime}$ & $37^{\circ} 26^{\prime} 5^{\prime \prime}$ & $37^{\circ} 26^{\prime} 30^{\prime \prime}$ \\
\hline Longitude (E) & $100^{\circ} 18^{\prime} 13^{\prime \prime}$ & $100^{\circ} 17^{\prime} 12^{\prime \prime}$ & $100^{\circ} 19^{\prime} 19^{\prime \prime}$ & $102^{\circ} 37^{\prime} 12^{\prime \prime}$ & $102^{\circ} 38^{\prime} 24^{\prime \prime}$ & $103^{\circ} 42^{\prime} 24^{\prime \prime}$ & $103^{\circ} 41^{\prime} 38^{\prime \prime}$ \\
\hline Slope & $30^{\circ}$ & $7^{\circ}$ & $19^{\circ}$ & $31.5^{\circ}$ & $21^{\circ}$ & $30^{\circ}$ & $30^{\circ}$ \\
\hline CC $(\%)$ & 50 & 45 & 40 & 60 & 50 & 45 & 40 \\
\hline $\mathrm{TD}(\mathrm{m})$ & 5.2 & 5.28 & 7.3 & 6.8 & 2.75 & 2.36 & 2.64 \\
\hline $\mathrm{DBH}(\mathrm{cm})$ & 40.03 & 30.78 & 31.14 & 44.44 & 32.34 & 85.8 & 89.7 \\
\hline $\mathrm{TH}(\mathrm{m})$ & 20.26 & 14.5 & 16.12 & 18.5 & 16 & 16.3 & 16.95 \\
\hline
\end{tabular}

CC (\%): canopy coverage, TD: tree distance, DBH: diameter at breast height, TH: tree height. P is the sampling site.

\subsection{Tree-Ring Chronology Development and Statistical Parameter Calculation}

The sample tree cores were fixed with latex in a wooden trough in the laboratory. The cores were air-dried and polished using 200-, 400-, and 600-mesh sandpapers until the tree-ring boundaries were clearly visible. After cross-dating with a microscope, the tree-ring width of each core was measured using the LINTAB Measurement System with an accuracy of $0.001 \mathrm{~mm}$ (TM6, Rinntech, Heidelberg, Germany), followed by quality control of the dating and measurement results using the COFECHA procedure [39]. To avoid interference from non-climatic factors, the ARSTAN procedure with negative exponential curves or linear regression eliminates growth trends in the original tree-wheel width series [38]. Standardized chronology (STD) is a chronology obtained by standardizing the ring width, eliminating the growth trend related to tree age and the influence of 
individual differences of trees, and then eliminating the samples with poor correlation with most sequences according to the correlation coefficient between index series and main series, and finally combining the two-weight average method [40]. STD were developed containing a strong climatic signal and retaining more growth variability information with low frequency $[41,42]$. In order to facilitate the study of the three different regions, we classified the data into different altitudes in the same region in turn and combined them for further analysis (Table 2).

To assess the reliability and quality of the chronology, statistical characteristic parameters of the tree-ring width chronology were also calculated using the ARSTAN procedure [43,44] (Table 2), including mean sensitivity (MS), standard deviation (SD), first-order serial autocorrelation (ACI), mean correlation coefficients between series (R1, R2, and R3), amount of variance explained by the first principal component, signal-to-noise ratio (SNR), and expressed population signal (EPS). MS is a statistic that measures year-to-year changes in tree-ring width. The standard deviation reflects the interannual variability of each chronology. AC1 represents the effect of the previous year's climate on the current year's growth. PC1 indicates the percentage of variance explained by the first component in a principal component analysis. $R$ reflects the common signal strength among chronologies. SNR and EPS represent the intensity of the common climate information between chronologies, and a chronology was used for dendroclimatological analysis with EPS $>0.85$ [45].

Table 2. Dendrochronological characteristics of chronologies for the Qinghai spruce.

\begin{tabular}{cccc}
\hline Sites & Central Region & Eastern Region & Isolated Mountain \\
\hline Core/tree & $145 / 75$ & $92 / 46$ & $149 / 77$ \\
Time period & $1902-2018$ & $1943-2018$ & $1936-2018$ \\
MS & 0.237 & 0.154 & 0.306 \\
SD & 0.294 & 0.336 & 0.284 \\
AC1 & 0.552 & 0.156 & 0.218 \\
R1 & 0.487 & 0.273 & 0.562 \\
R2 & 0.684 & 0.469 & 0.733 \\
R3 & 0.480 & 0.403 & 0.542 \\
PC1 & 0.564 & 0.416 & 0.611 \\
SNR & 57.56 & 23.79 & 13.97 \\
EPS & 0.970 & 0.950 & 0.930 \\
\hline
\end{tabular}

\subsection{Data Analysis}

We calculated Pearson correlation coefficients between STD and climatic factors for the Qinghai spruce in three regions from 1957 to 2018 in order to determine the main limiting factors controlling radial growth. To analyze the effects of drought duration and intensity on tree growth, we also calculated Pearson correlation coefficients between chronologies and SPEI at 1-, 3-, 6-, and 12-month time scales. The dynamic relationship between the radial growth of trees and the dominant climatic factors was calculated using the moving correlation function (shifted backward from a fixed year in 1957 with an interval of 30 years). We also calculated spatial Pearson correlations for large-scale spatial patterns that drive radial tree growth. Calculations were performed using the (http://climexp.knmi.nl/, accessed on 26 February 2020) website using the Climate Research Unit version 3.22 of the Climate Database with $0.5 \times 0.5$ grid data.

Basal area increase $(B A I)$ as a more physiologically meaningful variable to quantify and describe patterns and trends in radial tree growth was calculated. The negative growth of $B A I$ can indicate that the basal area increases are inhibited. The equation for calculating $B A I$ is as follows:

$$
B A I=\pi\left(R_{t}^{2}-R_{t-1}^{2}\right)
$$

where $R$ represents the radius of the corresponding tree, and $t$ is the year of the tree whorl formation. 


\section{Results}

\subsection{Tree-Ring Chronology Statistical Characteristics}

The characteristics of tree-ring width chronologies in the three regions are shown in Table 2. The EPS values were all greater than 0.85 and the values of SNR were 57.56, 23.79, and 13.97 in the three regions, indicating the higher quality and more climate information of the developed chronologies. Therefore, the chronologies of the three regions are all suitable for analyzing the relationship between radial growth and climate factors. In terms of other chronological data, we found that the values of MS, R, and PC1 in the isolated mountain were higher than the central and eastern parts of the Qilian Mountains, indicating that the climate sensitivity of tree rings in this region was the highest.

\subsection{Radial Growth Trends of the Qinghai Spruce in Different Regions}

Figure 4 shows the interannual variation of the tree-ring width chronologies and BAI of trees in the three regions in 1957-2018. The chronology and BAI of the central region showed an increasing followed by a decreasing trend, and BAI showed an increasing trend with an increase rate of $3.18 \mathrm{~cm}^{2} / 10 \mathrm{a}$ in 1957-1983 and a decreasing trend with a decreasing rate of $-2.2 \mathrm{~cm}^{2} / 10$ a from 1983 to 2018. The chronology and BAI of the eastern region showed a steadily increasing trend with a rate of $4.2 \mathrm{~cm}^{2} / 10$ a for BAI. However, the chronology and BAI of isolated mountains showed a decreasing rate of $-0.89 \mathrm{~cm}^{2} / 10 \mathrm{a}$ for BAI.
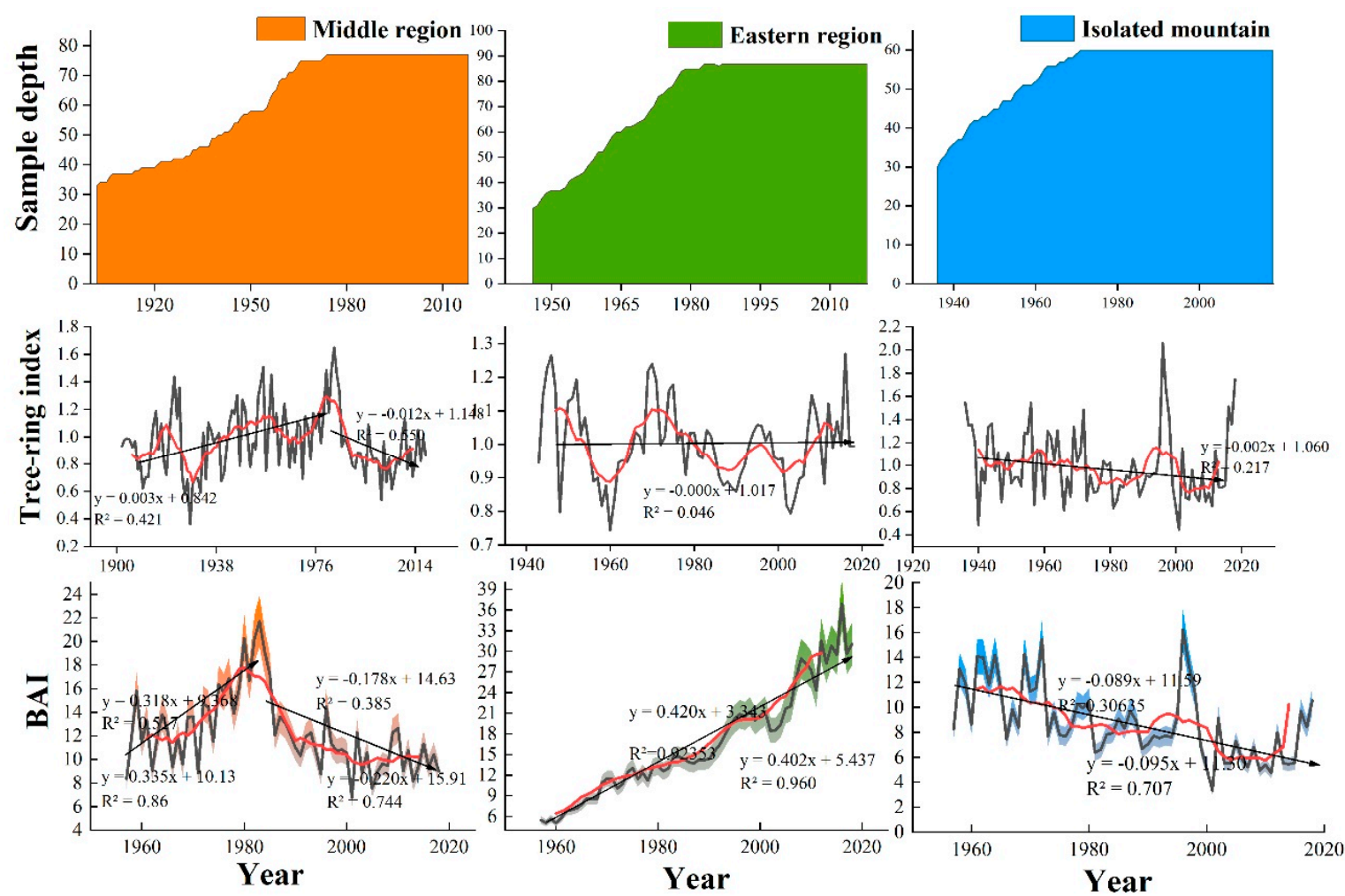

Figure 4. Interannual variabilities of tree-ring width and basal area increment (BAI) in three Central and Eastern Qilian Mountain regions.

\subsection{Correlations between the Radial Growth of Qinghai Spruce and Climatic Factors in Different Regions}

The correlations between radial growth of Qinghai spruce and climatic factors are illustrated in Figure 5. The radial growth in the central region was significantly negatively correlated with the mean maximum temperature $(\mathrm{r}=-0.487, p<0.01 ; \mathrm{r}=-0.283, p<0.05)$, mean minimum temperature $(\mathrm{r}=-0.298, p<0.05 ; \mathrm{r}=-0.297, p<0.05)$, and mean temperature $(\mathrm{r}=-0.315, p<0.05 ; \mathrm{r}=-0.315, p<0.05)$ in June-July of the growing season 
of the current year. On the other hand, there was no significant correlation between the radial growth and climatic factors in the eastern region. However, the radial growth in the isolated mountain significantly negatively correlated with the mean minimum temperature in September $(r=-0.315, p<0.05)$ at the end of the growing season of the current year, and significantly positively correlated with the total precipitation in September $(r=0.25$, $p<0.05)$ at the end of the growing season of the previous year in March $(r=0.298, p<0.05)$ and July $(r=0.307, p<0.05)$ in the growing season of the current year.
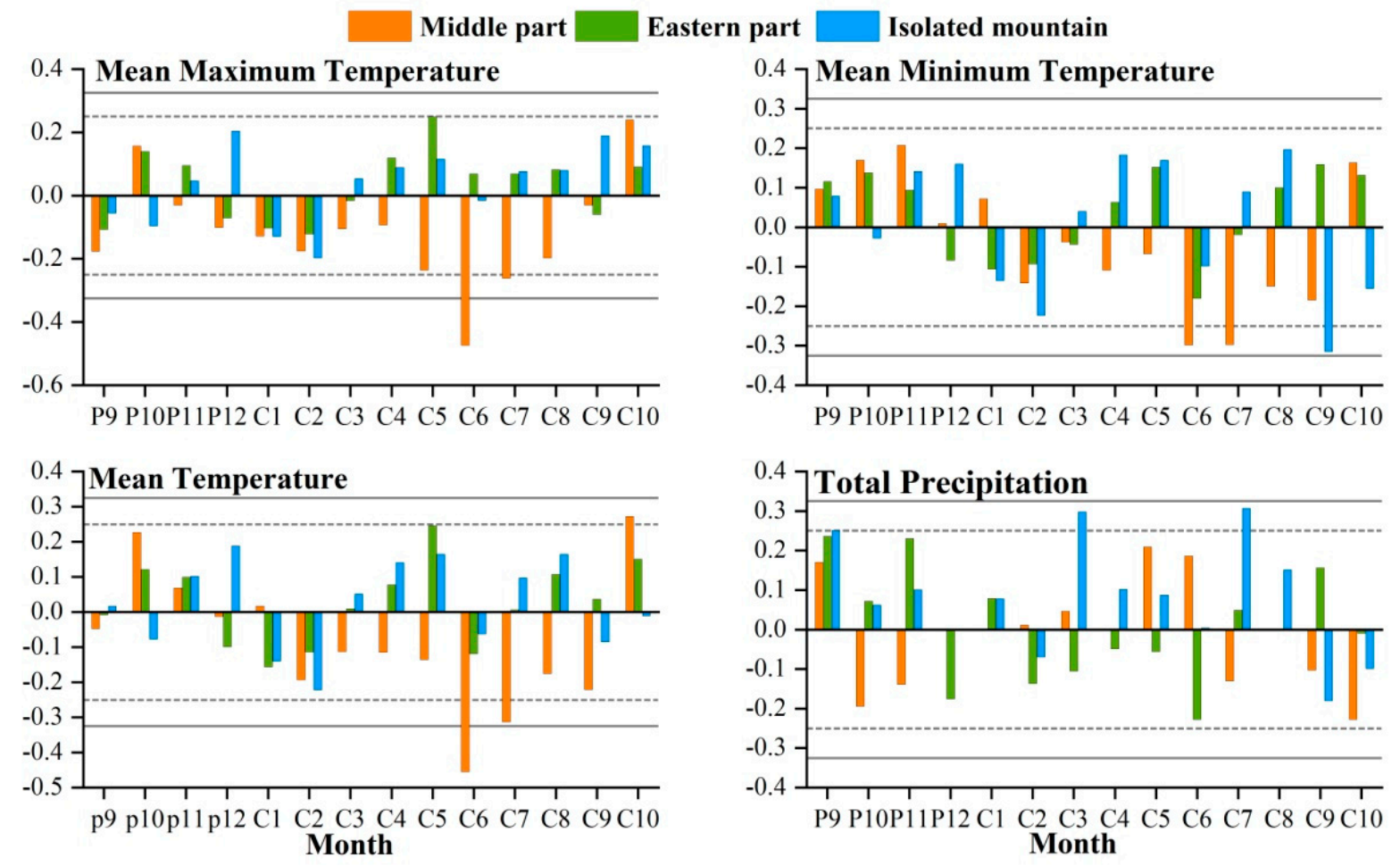

Figure 5. Correlations between tree-ring width chronologies and climatic factors in the three Central and Eastern Qilian Mountain regions.

The radial growth of trees was negatively correlated with the temperature in the growing season and positively correlated with precipitation, indicating that drought stress is the dominant factor affecting the radial growth. Therefore, we investigated the relationships between tree-ring width chronologies and the SPEI at different time scales (Figure 6). The correlation between SPEI and radial growth is mainly calculated by Pearson correlation in SPSS software. Among them, the growth of trees in the central region and isolated mountains of the Qilian Mountains were more susceptible to drought stress than in the eastern region, showing that the significant responses were mainly concentrated with SPEI from May to August of the current year growing season (Figure 6). In particular, the radial growth of trees in the central region had significant correlations with SPEI3 $(r=0.377$, $p<0.01)$, SPEI6 $(\mathrm{r}=0.367, p<0.01)$, and SPEI12 $(\mathrm{r}=0.468, p<0.01)$ in June, and SPEI3 $(r=0.254, p<0.05)$, SPEI6 $(r=0.284, p<0.05)$, and SPEI12 $(r=0.413, p<0.01)$ in July of the current year. The radial growth of trees in the isolated mountain showed a significant positive response with the SPEI1 $(r=0.333, p<0.01)$ and SPEI12 $(r=0.524, p<0.01)$ in July of the current year. 


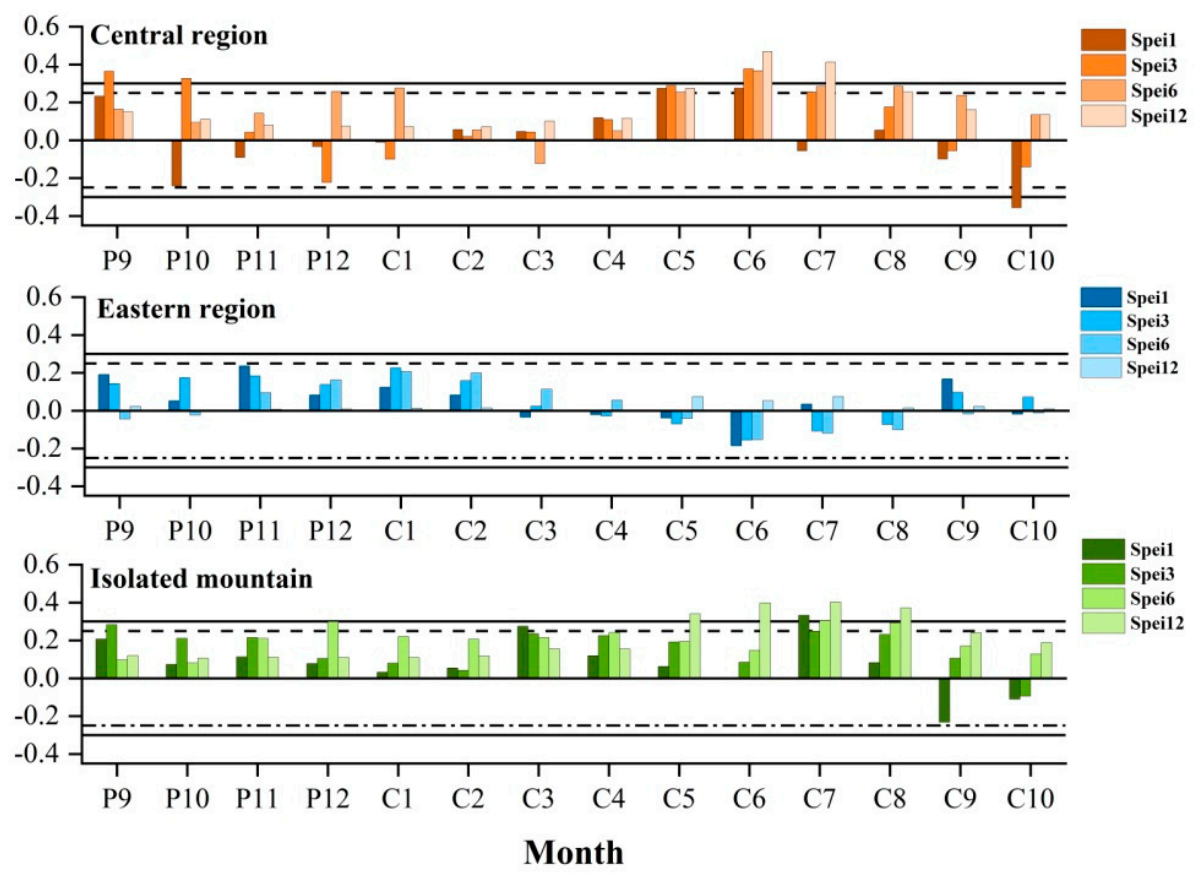

Figure 6. Correlations between tree-ring width chronologies and standardized precipitation evapotranspiration index (SPEI) in the three Central and Eastern Qilian Mountain regions.

\subsection{Spatial Correlations between Radial Growth and Climatic Factors of the Qinghai Spruce in} Different Regions

We further analyzed the spatial correlation between tree radial growth and main climate factors. The correlations were calculated on the following website: (http:/ / climexp. $\mathrm{knmi} . \mathrm{nl} /$, accessed on 20 May 2021). There was a significantly negative spatial correlation between the radial growth in the central region and the mean maximum temperature and mean temperature in June of the current year, and the further west in the Qilian Mountains, the more significant the correlation (Figure 7). The radial growth of isolated mountains had a significantly positive correlation with the mean minimum temperature in September of the current year, and a significantly negative correlation with the total precipitation in July of the current year (Figure 7). Based on the spatial correlation results of the two regions, the drought stress caused by temperature and precipitation in the growing season of the current year is the main factor limiting condition for the trees' growth.

\subsection{Stability Response of the Qinghai Spruce to Climate Change in Different Regions}

According to the results of growth-climate relationships, the drought stress caused by temperature and precipitation is the main limiting factor of the radial growth of trees in the central region and isolated mountains. Therefore, the stability responses of radial growth were further assessed with the moving correlation function. The moving correlation was calculated by placing chronological data and climate data in the software named "DendroClim 2002" by setting the moving window to 30 years. After the program was run, the moving correlation results of 30 years were obtained.

Trees in the central region showed progressively stronger negative correlations with mean maximum temperature, mean minimum temperature, mean temperature, and SPEI in June-July of the current year (Figure 8). The negative response of trees in the isolated mountains to the mean minimum temperature in September of the current year and the positive correlation with the total precipitation in March and July of the current year gradually strengthened, and the positive correlation with the total precipitation in September of the previous year gradually weakened (Figure 8 ). In addition, the isolated mountain showed a stable positive correlation with SPEI in September of the previous year $(p<0.05)$. 

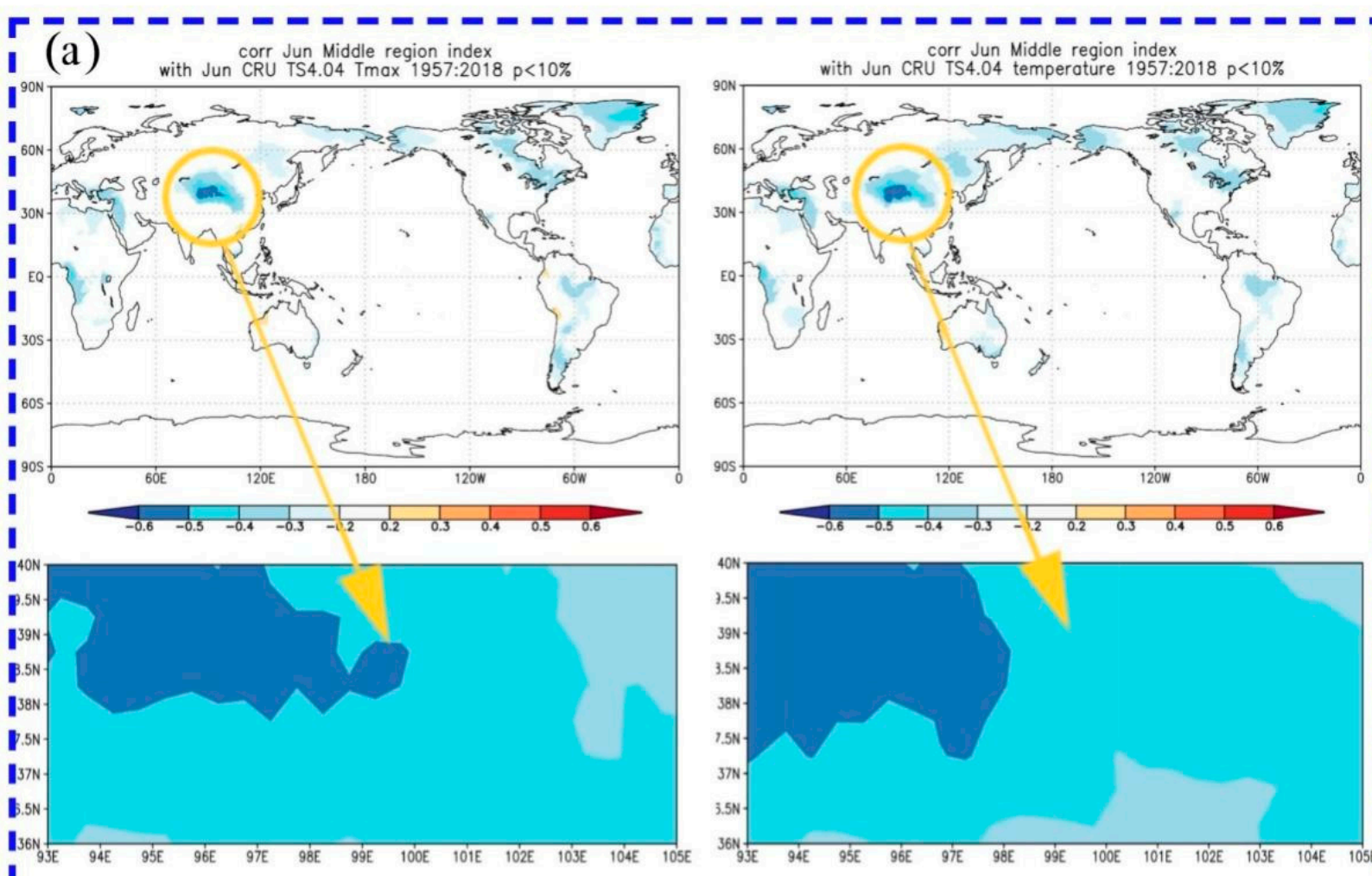

(b)

corr Sep Isolated mountain index
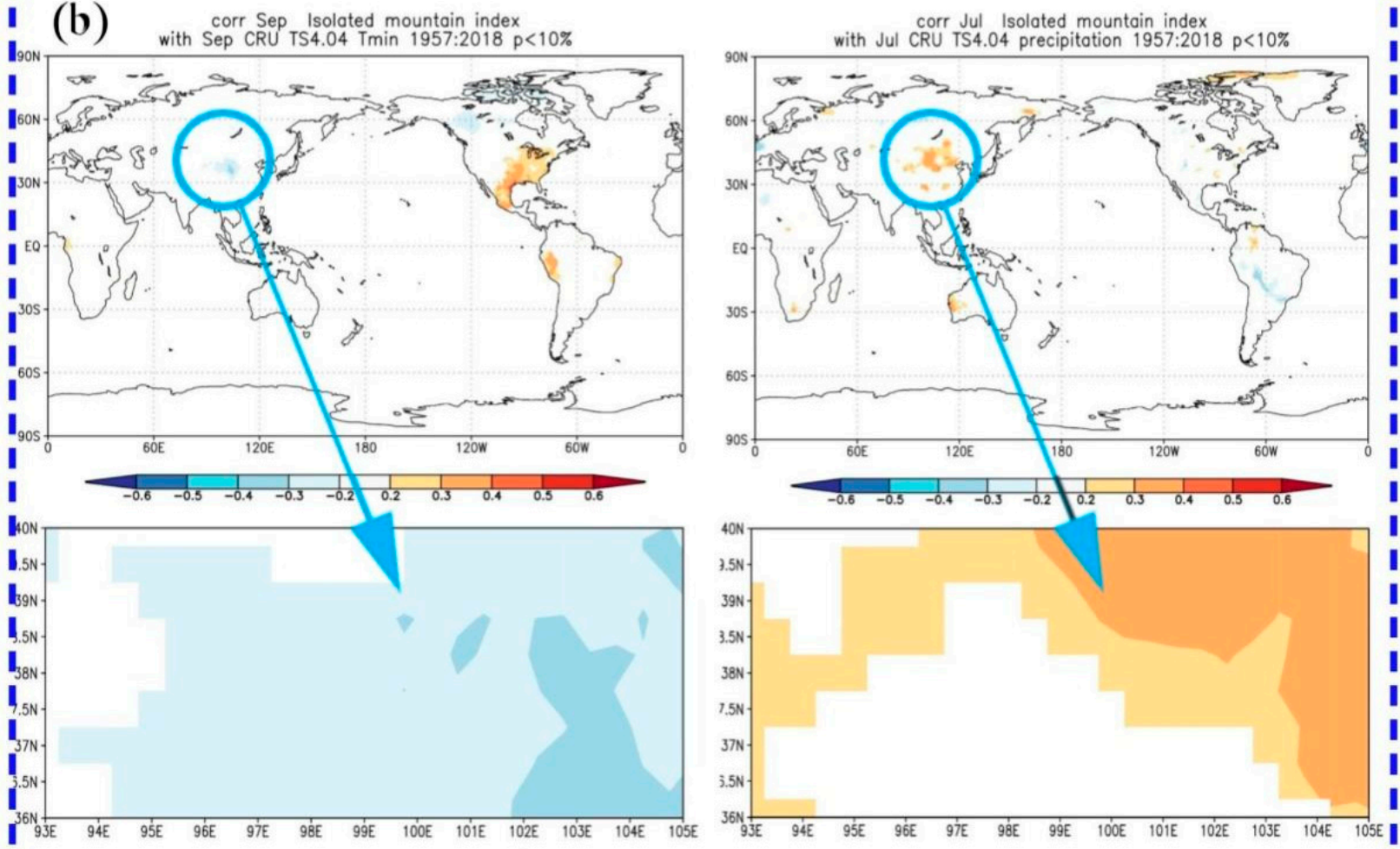

ᄂ

Figure 7. Spatial correlations between tree-ring width chronologies and main climate factors. The circles indicate that the approximate location of the study regions and the field correlations were $p<0.10$ in all cases. (a) Central region, and (b) isolated mountains. 
(a)

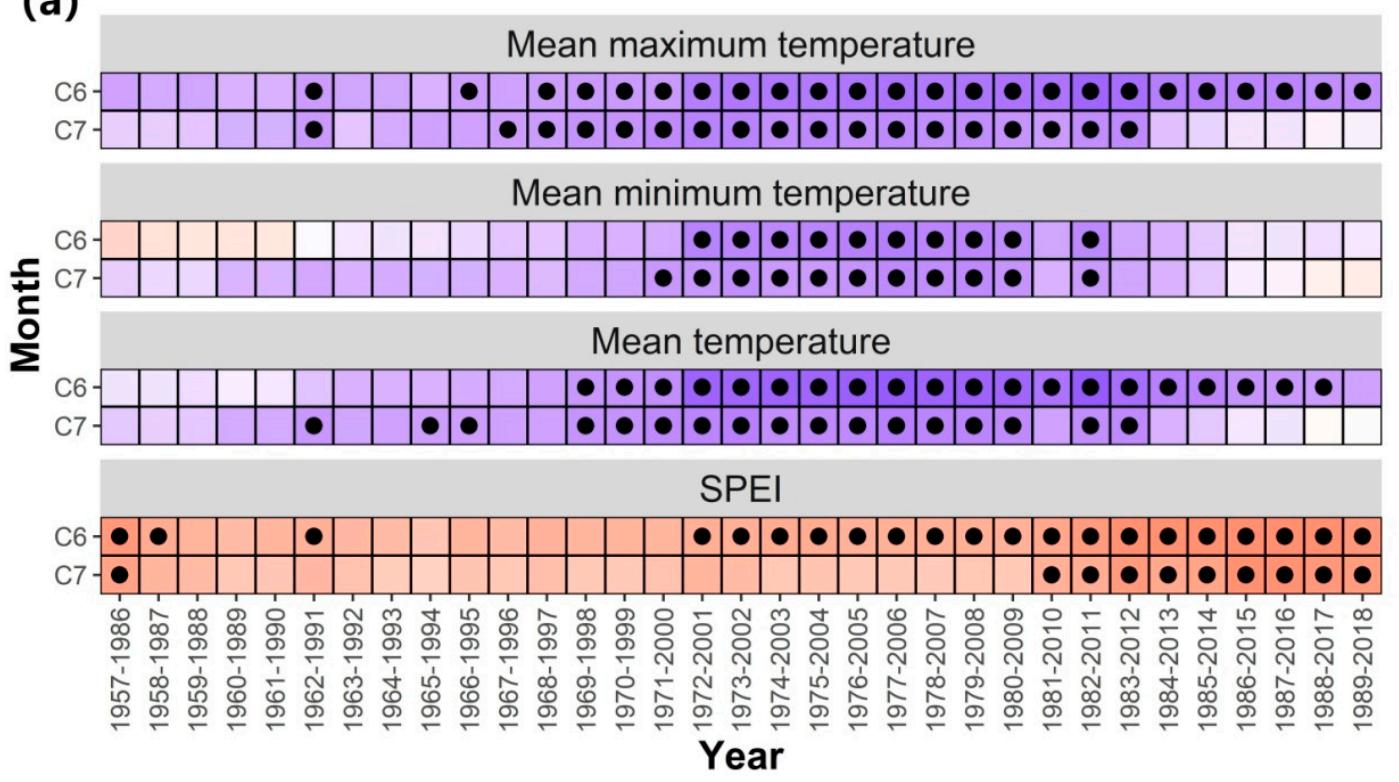

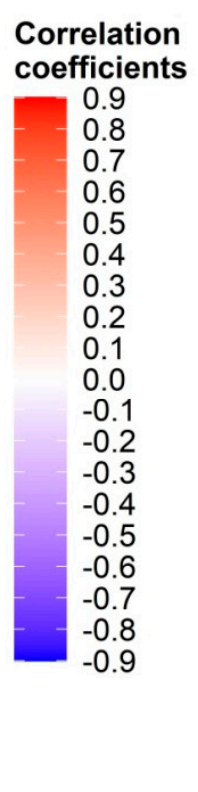

(b)

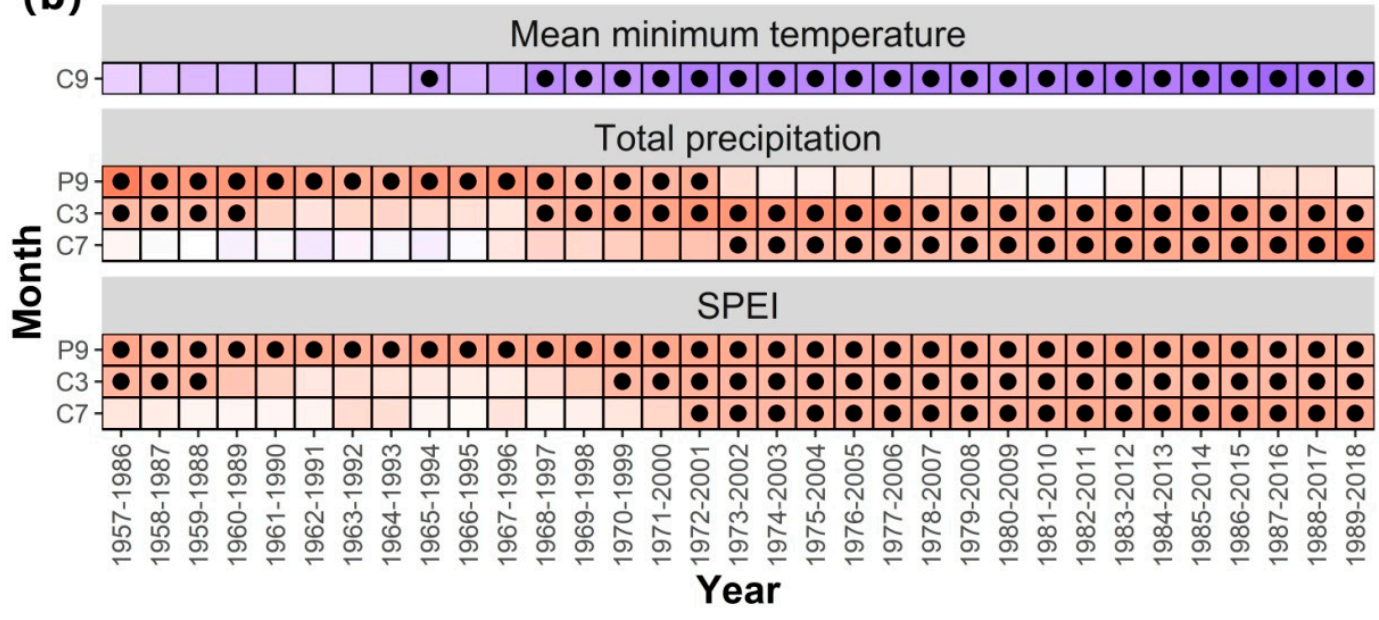

\section{Correlation}

coefficients

0.9
0.8
0.7
0.6
0.5
0.4
0.3
0.2
0.1
0.0
-0.1
-0.2
-0.3
-0.4
-0.5
-0.6
-0.7
-0.8
-0.9

Figure 8. Moving correlations between the tree-ring width chronologies and climate factors in two regions. (a) Central region, and (b) isolated mountains.

\section{Discussion \\ 4.1. Discrepancies in the Dominant Climatic Factors Controlling Radial Growth of Trees in Different Regions}

In recent decades, global warming has changed the climate in Northwest China from warm-dry to warm-wet [46]. Therefore, the recent climate change profoundly affects the ecological and physiological processes of the forest system [47]. Therefore, we investigated the responses of radial growth of the Qinghai spruce to environmental conditions in different regions of the Qilian Mountains and confirmed that drought is the main factor for radial growth. This finding is consistent with the observations in other forest systems in arid and semi-arid regions [48-50]. The central region of the Qilian Mountains is at a higher altitude $(3300 \mathrm{~m})$ and the radial growth depends on the water availability due to the increased temperature [51]. The increasing temperature aggravates the drought stress, causing soil water evaporation, water shortage of roots, and excessive water loss of trees, leading to stomatal closure or partial closure, which reduces the photosynthetic efficiency of trees (Figure 2). At the same time, the respiration intensity of leaves and roots consumes 
more and more of the limited organic matter accumulated during photosynthesis, thereby affecting the physiological activities of trees [52,53].

According to the results of a Pearson correlation and spatial correlation, the drought stress caused by the increase in temperature in the growing season is the main factor restricting the growth of trees in the central region (Figures 5 and 7). The Qinghai spruce is a late-growing tree species with vigorous growth in the summer [54]. Thus, tree growth is most relevant to summer climate factors [55]. If the tree habitat is humid enough, the higher temperature promotes photosynthesis and carbon accumulation [56], but the water resources in the habitat are not conducive to photosynthesis, and the positive effect of warming on carbon accumulation is eliminated [57]. Compared to the western region with less precipitation, the eastern part of the Qilian Mountains has more water (the annual total precipitation is $329.4 \mathrm{~mm}$ ). Even with the rising temperature, the growth of trees in this region is not affected by drought stress, which is consistent with the result that the growth of trees in this region has a positive response to summer temperature and no significant correlation with SPEI (Figures 5 and 6). This relationship was also observed in other areas with higher rainfall $[15,58,59]$. SPEI correlation results showed that the trees in the central region and isolated mountains were subjected to different degrees of drought stress. The radial growth of the isolated mountain had a significantly positive correlation with the total precipitation in March and July of the current year, and a significantly negative correlation with the mean minimum temperature in September of the current year (Figure 5). The isolated mountains located at the southern edge of the Tengger Desert are geographically influenced by low overall precipitation, high temperatures, and high evapotranspiration, which predispose them to drought stress and lead to the increased sensitivity of radial growth to water effectiveness [60]. Some studies reported similar relationships for stem growth variation, ring deficiency frequency, and tree mortality in Qinghai spruce, and these growth responses are usually limited by the water effectiveness caused by drought stress, providing convincing evidence for our findings [61,62]. Therefore, trees' vigor may be more seriously affected by the increase in the duration and intensity of drought stress in the study area.

\subsection{Assessment of Tree Growth-Climate Stability in Different Regions}

The unstable response of tree radial growth to climate change is a challenge to the application of traditional tree chronology [8]. Therefore, it is necessary to carry out validation research in larger areas and on key tree species. According to the results of this study, there are significant differences between the radial growth of Qinghai spruce and the response stability of climate factors in the three regions.

There was no stable relationship between the tree growth and the mean maximum temperature, mean minimum temperature, and mean temperature in June and July of the growing season and SPEI in the central region. However, the negative correlation with temperature and the positive correlation with SPEI gradually increased over time (Figure 8). The tree growth of the isolated mountain had no stable response with mean minimum temperature in September of the current year, and precipitation and SPEI in March and July of the current year. In particular, the growth response to the total precipitation in July changed from negative to positive. In addition, it maintained a stable positive correlation with SPEI in September of the previous year (Figure 8).

The response to radial growth seems to vary greatly between environments depending on the size and number of rows of xylem mother cells and on the climate, topography, age, vitality, competition, etc. [63]. Thus, regional climate variability could explain the differences in radial growth stability to climate change. Firstly, the temperature in the central region was the lowest among the three regions, and climate warming promoted the radial growth of Qinghai spruce at a relatively higher altitude, which indicated that the tree growth in the early period benefited from the gradually increasing temperature during the growing season. When the temperature crossed the threshold of what the trees could tolerate, it showed a negative correlation with temperature and the drought stress 
gradually increased, and the above results indicated that there was an unstable relationship between tree growth and temperature in the Qilian Mountains, which is consistent with the observed response relationship, and this relationship was also confirmed in many previous studies $[15,22,64,65]$.

In the isolated mountain region, the precipitation decreased sharply, and was accompanied by an increase in temperature at the end of the previous year (the "lag effect"), which led to the enhancement of the respiration of trees, a decrease in photosynthetic products' accumulation, and the narrowing of the tree-ring width [66,67]. Therefore, the negative response of the radial growth of trees to the mean minimum temperature was gradually enhanced as the temperature increased (Figure 8). Meanwhile, drought stress in March appears due to the total precipitation being less and the temperature rising. However, although the total precipitation in July of the growing season was more than that in March, the water availability in the soil was inhibited and the drought stress increased with the rising temperature and the intensification of evaporation. This unstable relationship between total precipitation and tree growth has also been confirmed by numerous previous studies $[34,55,68]$. Tree growth is subject to local climatic conditions rather than a wide geographic gradient $[69,70]$. There are differences in altitude, temperature, precipitation, and other climatic conditions between the three regions. The results showed that the relationship between the growth and climate factors of the same tree species was not stable in different regions of the Qilian Mountains. Trees in different regions adopted different adaptation strategies to cope with climate change.

\subsection{Projections of Growth Patterns of Trees in Different Regions}

Climate change is complicating the relationship between tree growth and the regional climate. Many reports have shown different growth trends of the Qinghai spruce in different regions such as Gansu [55], Sichuan [65], and the Qinghai-Tibet Plateau [71]. Our results showed that the radial growth patterns of trees varied in different regions of the Qilian Mountains in 1957-2018, as evidenced by the increasing trend $\left(3.35 \mathrm{~cm}^{2} / 10 \mathrm{a}\right.$, $p<0.05)$ and then a decreasing trend $\left(-2.2 \mathrm{~cm}^{2} / 10 \mathrm{a}, p<0.05\right)$ in the central region, an increasing trend $\left(4.02 \mathrm{~cm}^{2} / 10 \mathrm{a}, p<0.05\right)$ in the eastern part, and a steadily decreasing trend $\left(-0.95 \mathrm{~cm}^{2} / 10 \mathrm{a}, p<0.05\right)$ in the isolated mountain (Figure 4).

The Qinghai spruce typically grows in a cold environment, so the tree needs to adjust its ecological physiological processes to adapt to rapid warming [56,72], and higher temperatures can promote photosynthesis and respiration [73]. Therefore, trees in the cold central region experienced significant growth due to a large amount of carbon accumulation in the early stages under favorable climate conditions. There was a certain threshold range for the sensitivity of Qinghai spruce to temperature, namely, the "temperature threshold effect" [74-76]. However, the increasing temperature gradually exceeded the threshold temperature of trees in the central region $\left(0.13^{\circ} \mathrm{C} / 10 \mathrm{a}\right)$. The high temperature in summer in the growth season may also lead to more complex physiological processes of trees, such as a decrease in the horizontal stomatal conductance of leaves [77], inhibition of enzyme activity [78], and delayed stem flow [79], which may affect the radial growth of trees and decrease the growth trend. This is consistent with the result that initial correlation with mean maximum temperature, mean minimum temperature, mean temperature, and SPEI is lacking, but the later response is gradually increasing. It indicates that the growth of trees in this region did not fully benefit from the warming of the relatively cold region in 1957-2018, showing the dominant role of drought stress rather than cold stress in their growth at a later stage. This is similar to the results of related studies in the Tibetan Plateau region [80]. In contrast, the higher precipitation in the eastern part allows the effectiveness of soil moisture to be replenished, suppressing the negative effects of high temperature on tree growth, and the elevated temperature further promotes photosynthesis and carbon accumulation $[81,82]$. Thus, the increasing temperature in humid areas may be more favorable for tree growth compared to the central areas and could play an important role in regulating the growth-temperature relationship in the study area. This is consistent 
with the results that the region is not subject to high temperature and drought and has no positive response to the SPEI, so tree growth is expected to continue to increase (Figure 6). The isolated mountain is located in the southern edge of the Tengger Desert, where the temperature is the highest among the three regions, with less precipitation and large evaporation. The long-term drought restriction aggravated soil transpiration, decreased water use efficiency, and inhibited root development, cambium activity, nutrient storage, leaf efficiency, and early wood proportion. At the same time, less water available in the soil could not inhibit the negative effects of high temperature, so the growth trend would continue to decline with the increase in temperature in the future, which was consistent with the stable positive response of tree growth and SPEI (Figure 8).

Rising temperatures are increasing the intensity and frequency of drought in many regions, negatively affecting forest ecosystems [83]. In this context, forest ecosystems in arid and semi-arid regions are close to drought limits and are particularly sensitive to climate change [84]. Our results suggest that growth patterns have complex responses to drought stress in different regions of the Qilian Mountains. Therefore, we should pay more attention to the radial growth patterns and spatial differences of tree species in response to climate change.

\section{Conclusions}

With the change in the global climate, the typical climate in northwest China has changed from warm and dry to warm and wet. Drought stress in the growing season is a common factor limiting the growth of trees in the central region and isolated mountains, with warmer conditions with less precipitation, while there was no drought stress in the eastern region with humid climate. Therefore, a gradually increasing growth trend was found in the eastern region. However, the increasing and then decreasing trend of trees and the unstable dynamic growth-climate relationship in the central region were due to the growth increase of trees benefiting from the temperature increase in the short term and the growth decreases when the temperature exceeds the threshold at the later stage. Meanwhile, the gradual decline in growth trend was accompanied by stable responses to SPEI. This finding helps us to further explore the "divergence problem" of tree growth in the Qilian Mountains. At the same time, we can also predict that the growth trend of trees in the eastern region will increase, while that in the central and isolated mountains will decrease, based on current trend analysis. It provides key information for clarifying the species-climate response and for understanding the ecological strategies of trees in forest systems. Therefore, it is important to carry out reasonable management and dynamic monitoring of subalpine forest ecosystems according to the climate characteristics of trees in different arid and semi-arid areas.

Author Contributions: Study conception and experimental design: L.J. and X.W.; Acquisition and processing of samples: D.D., C.Q. and R.X.; Analysis and interpretation of data: L.J. and X.W.; Drafting of manuscript: L.J. and X.W. All authors have read and agreed to the published version of the manuscript.

Funding: This research was supported by the National Natural Science Foundation of China (Grant No. 41861006), the Natural Science Foundation of Gansu Province (No. 20JR10RA093), and the Research Ability Promotion Program for Young Teachers of Northwest Normal University (NWNULKQN2019-4).

Data Availability Statement: No data were reported in this study.

Acknowledgments: We thank the anonymous referees for helpful comments on the manuscript.

Conflicts of Interest: The authors declare no conflict of interest. 


\section{References}

1. Deng, Y.; Gou, X.; Gao, L.; Zhao, Z.; Cao, Z.; Yang, M. Aridity changes in the eastern Qilian Mountains since AD 1856 reconstructed from tree-rings. Quat. Int. 2013, 283, 78-84. [CrossRef]

2. Alkama, R.; Cescatti, A. Biophysical climate impacts of recent changes in global forest cover. Science 2016, 351, 600-604. [CrossRef] [PubMed]

3. Zhang, Y.; Wilmking, M.; Gou, X.; Valk, A.G. Changing relationships between tree growth and climate in Northwest China. For. Ecol. 2008, 39-50. [CrossRef]

4. Stocker, T.; Qin, D.; Plattner, G.; Tignor, M.; Allen, S.; Boschung, J.; Nauels, A.; Xia, Y.; Bex, V.; Midgley, P. Climate Change 2013: The Physical Science Basis. Contribution of Working Group I to the Fifth Assessment Report of the Intergovernmental Panel on Climate Change; Cambridge University Press: Cambridge, UK, 2013; pp. 33-115.

5. IPCC (Intergovernmental Panel on Climate Change). Climate Change 2001: Synthesis Report. A Contribution of Working Groups I, II and III to the Third Assessment Report of the Intergovernmental Panel on Climate Change; Watson, R.T., The Core Writing Team, Eds.; Cambridge University Press: Cambridge, UK, 2001.

6. Beniston, M. Climate modeling at various spatial and temporal scales: Where can dendrochronology help? Dendrochronologia 2002, 20, 117-131. [CrossRef]

7. Fritts, H. Tree Rings and Climate; Elsevier: Amsterdam, The Netherlands, 2012.

8. D'Arrigo, R.; Wilson, R.; Liepert, B.; Cherubini, P. On the 'Divergence Problem' in Northern Forests: A review of the tree-ring evidence and possible causes. Glob. Planet. Chang. 2008, 60, 289-305. [CrossRef]

9. Jiao, L.; Jiang, Y.; Zhang, W.; Wang, M.; Wang, S.; Liu, X. Assessing the stability of radial growth responses to climate change by two dominant conifer trees species in the Tianshan Mountains, northwest China. For. Ecol. Manag. 2019, 433, 667-677. [CrossRef]

10. Lyu, S.; Wang, X.; Zhang, Y.; Li, Z. Different responses of Korean pine (Pinus koraiensis) and Mongolia oak (Quercus mongolica) growth to recent climate warming in northeast China. Dendrochronologia 2017, 45, 113-122. [CrossRef]

11. Wild, R. To Examine How the Radial Growth Patterns of Different Species of Trees May Vary after Being Exposed to the Same Annual Climatic Conditions: A Priestley Clough Case Study. Doctoral Dissertation, University of Central Lancashire, Preston, Lancashire, UK, 2013.

12. Li, Z.S.; Liu, G.H.; Fu, B.J.; Hu, C.J.; Luo, S.Z.; Liu, X.L.; He, F. Anomalous temperature-growth response of Abies faxoniana to sustained freezing stress along elevational gradients in China's Western Sichuan Province. Trees 2012, 26, 1373-1388. [CrossRef]

13. Büntgen, U.; Frank, D.; Grudd, H.; Esper, J. Long-term summer temperature variations in the Pyrenees. Clim. Dyn. 2008, 31, 615-631. [CrossRef]

14. LeBourgeois, F.; Mérian, P.; Courdier, F.; Ladier, J.; Dreyfus, P. Instability of climate signal in tree-ring width in Mediterranean mountains: A multi-species analysis. Trees 2011, 26, 715-729. [CrossRef]

15. Gazol, A.; Camarero, J.J.; Gutiérrez, E.; Popa, I.; Andreu-Hayles, L.; Motta, R.; Nola, P.; Ribas, M.; Sangüesa-Barreda, G.; Urbinati, C.; et al. Distinct effects of climate warming on populations of silver fir (Abies alba) across Europe. J. Biogeogr. 2015, 42, 1150-1162. [CrossRef]

16. Holz, A.; Hart, S.J.; Williamson, G.; Veblen, T.T.; Aravena, J.C. Radial growth response to climate change along the latitudinal range of the world's southernmost conifer in southern South America. J. Biogeogr. 2018, 45, 1140-1152. [CrossRef]

17. Takahashi, K.; Tokumitsu, Y.; Yasue, K. Climatic factors affecting the tree-ring width of Betula ermanii at the timberline on Mount Norikura, central Japan. Ecol. Res. 2005, 20, 445-451. [CrossRef]

18. Fekedulegn, D.; Hicks, R.R.; Colbert, J.J. Influence of topographic aspect, precipitation and drought on radial growth of four major tree species in an Appalachian watershed. For. Ecol. Manag. 2003, 177, 409-425. [CrossRef]

19. Rigling, A.; Bräker, O.; Schneiter, G.; Schweingruber, F. Intra-annual tree-ring parameters indicating differences in drought stress of Pinus sylvestris forests within the Erico-Pinion in the Valais (Switzerland). Plant Ecol. 2002, 163, 105-121. [CrossRef]

20. Kiaei, M.; Bakhshi, R. A dendrochronological study on Acer velutinum in northern Iran. J. Sci. Technol. 2011, 4, 1547-1550. [CrossRef]

21. del Castillo, E.M.; Prislan, P.; Gričar, J.; Gryc, V.; Merela, M.; Giagli, K.; de Luis, M.; Vavrčík, H.; Čufar, K. Challenges for growth of beech and co-occurring conifers in a changing climate context. Dendrochronologia 2018, 52, 1-10. [CrossRef]

22. Knutzen, F.; Dulamsuren, C.; Meier, I.C.; Leuschner, C. Recent Climate Warming-Related Growth Decline Impairs European Beech in the Center of Its Distribution Range. Ecosystems 2017, 20, 1494-1511. [CrossRef]

23. Roibu, C.-C.; Popa, I.; Kirchhefer, A.J.; Palaghianu, C. Growth responses to climate in a tree-ring network of European beech (Fagus sylvatica L.) from the eastern limit of its natural distribution area. Dendrochronologia 2017, 42, 104-116. [CrossRef]

24. Shen, M.; Piao, S.; Dorji, T.; Liu, Q.; Cong, N.; Chen, X.; An, S.; Wang, S.; Wang, T.; Zhang, G. Plant phenological responses to climate change on the Tibetan Plateau: Research status and challenges. Natl. Sci. Rev. 2015, 2, 454-467. [CrossRef]

25. Liang, E.; Shao, X.; Eckstein, D.; Liu, X. Spatial variability of tree growth along a latitudinal transect in the Qilian Mountains, northeastern Tibetan Plateau. Can. J. For. Res. 2010, 40, 200-211. [CrossRef]

26. Lei, J.; Feng, X.; Shi, Z.; Bai, D.; Xiao, W. Stability of relationship between climate and Picea crassifolia radial growth in different elevations. Acta Bot. Boreali-Occident. Sin. 2012, 32, 2518-2529.

27. Peng, S.; Zhao, C.; Xu, Z.; Ashiq, M.W. Restoration and conservation potential of destroyed Qinghai spruce (Picea crassifolia) forests in the Qilian Mountains of northwest China. Mitig. Adapt. Strat. Glob. Chang. 2014, 21, 153-165. [CrossRef] 
28. Wang, Y.; Lu, R.; Ma, Y.; Sang, Y.; Meng, H.; Gao, S. Annual variation in PDSI since 1897 AD in the Tengger Desert, Inner Mongolia, China, as recorded by tree-ring data. J. Arid Environ. 2013, 98, 20-26. [CrossRef]

29. Chen, F.; Yuan, Y.; Wei, W. Climatic response of Picea crassifolia tree-ring parameters and precipitation reconstruction in the western Qilian Mountains, China. J. Arid Environ. 2011, 75, 1121-1128. [CrossRef]

30. Chen, F.; Yuan, Y.-J.; Wei, W.-S.; Yu, S.-L.; Fan, Z.-A.; Zhang, R.-B.; Zhang, T.-W.; Li, Q.; Shang, H.-M. Temperature reconstruction from tree-ring maximum latewood density of Qinghai spruce in middle Hexi Corridor, China. Theor. Appl. Clim. 2011, 107, 633-643. [CrossRef]

31. Yu, L.; Huang, L.; Shao, X.; Xiao, F.; Wilmking, M.; Zhang, Y. Warming-Induced Decline of Picea crassifolia Growth in the Qilian Mountains in Recent Decades. PLoS ONE 2015, 10, e0129959. [CrossRef]

32. Jiao, L.; Xue, R.; Qi, C.; Chen, K.; Liu, X. Comparison of the responses of radial growth to climate change for two dominant coniferous tree species in the eastern Qilian Mountains, northwestern China. Int. J. Biometeorol. 2021, 1-14. [CrossRef]

33. Liang, E.; Leuschner, C.; Dulamsuren, C.; Wagner, B.; Hauck, M. Global warming-related tree growth decline and mortality on the north-eastern Tibetan plateau. Clim. Chang. 2015, 134, 163-176. [CrossRef]

34. Gao, L.; Gou, X.; Deng, Y.; Wang, Z.; Gu, F.; Wang, F. Increased growth of Qinghai spruce in northwestern China during the recent warming hiatus. Agric. For. Meteorol. 2018, 260-261, 9-16. [CrossRef]

35. Jiang, Y.; Kang, M.; Zhu, Y.; Xu, G. Plant biodiversity patterns on Helan Mountain, China. Acta Oecol. 2007, 32, 125-133. [CrossRef]

36. Biondi, F.; Waikul, K. DENDROCLIM2002: A C++ program for statistical calibration of climate signals in tree-ring chronologies. Comput. Geosci. 2004, 30, 303-311. [CrossRef]

37. Vicente-Serrano, S.M.; Beguería, S.; Lopez-Moreno, I. A Multiscalar Drought Index Sensitive to Global Warming: The Standardized Precipitation Evapotranspiration Index. J. Clim. 2010, 23, 1696-1718. [CrossRef]

38. Fritts, H. Tree Rings and Climate; Scientific American: New York, NY, USA, 1972; Volume 226, pp. 92-101.

39. Holmes, R.L. Computer-assisted quality control in tree-ring dating and measurement. Tree-Ring Bull. $1983,43,51-67$.

40. Helama, S. Expressing Tree-Ring Chronology as Age-Standardized Growth Measurements. For. Sci. 2015, 61, 817-828. [CrossRef]

41. Fritts, H. Tree Rings and Climate; Academic Press: London, UK, 1976; pp. 511-529.

42. Dang, H.; Zhang, Y.; Zhang, K.; Jiang, M.; Zhang, Q. Climate-growth relationships of subalpine fir (Abiesfargesii) across the altitudinal range in the Shennongjia Mountains, central China. Clim. Chang. 2012, 117, 903-917. [CrossRef]

43. Ahmed, M.; Palmer, J.; Khan, N.; Wahab, M.; Fenwick, P.; Esper, J.; Cook, E. The dendroclimatic potential of conifers from northern Pakistan. Dendrochronologia 2011, 29, 77-88. [CrossRef]

44. Yang, B.; He, M.; Melvin, T.M.; Zhao, Y.; Briffa, K.R. Climate Control on Tree Growth at the Upper and Lower Treelines: A Case Study in the Qilian Mountains, Tibetan Plateau. PLoS ONE 2013, 8, e69065. [CrossRef]

45. Wigley, T.M.L.; Briffa, K.R.; Jones, P.D. On the Average Value of Correlated Time Series, with Applications in Den-droclimatology and Hydrometeorology. J. Appl. Meteorol. Climatol. 1984, 23, 201-213. [CrossRef]

46. Shi, Y.; Shen, Y.; Kang, E.; Li, D.; Ding, Y.; Zhang, G.; Hu, R. Recent and Future Climate Change in Northwest China. Clim. Chang. 2006, 80, 379-393. [CrossRef]

47. Li, C.; Zhang, C.; Luo, G.; Chen, X.; Maisupova, B.; Madaminov, A.A.; Han, Q.; Djenbaev, B.M. Carbon stock and its responses to climate change in C entral A sia. Glob. Chang. Biol. 2015, 21, 1951-1967. [CrossRef] [PubMed]

48. Gentilesca, T.; Camarero, J.; Colangelo, M.; Nolè, A.; Ripullone, F. Drought-induced oak decline in the western Mediterranean region: An overview on current evidences, mechanisms and management options to improve forest resilience. iForest Biogeosciences For. 2017, 10, 796-806. [CrossRef]

49. Kurz-Besson, C.B.; Lousada, J.L.; Gaspar, M.J.; Correia, I.E.; David, T.; Soares, P.; Cardoso, R.M.; Russo, A.; Varino, F.; Mériaux, C.; et al. Effects of Recent Minimum Temperature and Water Deficit Increases on Pinus pinaster Radial Growth and Wood Density in Southern Portugal. Front. Plant. Sci. 2016, 7, 1170. [CrossRef] [PubMed]

50. Cahoon, S.M.P.; Sullivan, P.; Brownlee, A.H.; Pattison, R.R.; Andersen, H.; Legner, K.; Hollingsworth, T.N. Contrasting drivers and trends of coniferous and deciduous tree growth in interior Alaska. Ecology 2018, 99, 1284-1295. [CrossRef]

51. Jiao, L.; Jiang, Y.; Wang, M.; Kang, X.; Zhang, W.; Zhang, L.; Zhao, S. Responses to climate change in radial growth of Picea schrenkiana along elevations of the eastern Tianshan Mountains, northwest China. Dendrochronologia 2016, 40, 117-127. [CrossRef]

52. Rodríguez-Calcerrada, J.; Shahin, O.; Rey, M.D.C.D.; Rambal, S. Opposite changes in leaf dark respiration and soluble sugars with drought in two Mediterranean oaks. Funct. Plant. Biol. 2011, 38, 1004-1015. [CrossRef]

53. Wehr, R.; Munger, J.W.; McManus, J.B.; Nelson, D.D.; Zahniser, M.S.; Davidson, E.A.; Wofsy, S.C.; Saleska, S.R. Seasonality of temperate forest photosynthesis and daytime respiration. Nat. Cell Biol. 2016, 534, 680-683. [CrossRef]

54. Tian, Q.; He, Z.; Xiao, S.; Peng, X.; Ding, A.; Lin, P. Response of stem radial growth of Qinghai spruce (Picea crassifolia) to environmental factors in the Qilian Mountains of China. Dendrochronologia 2017, 44, 76-83. [CrossRef]

55. Wang, X.; Yang, B.; Li, G. Drought-induced tree growth decline in the desert margins of Northwestern China. Dendrochronologia 2020, 60, 125685. [CrossRef]

56. Dusenge, M.E.; Duarte, A.G.; Way, D.A. Plant carbon metabolism and climate change: Elevated CO2 and temperature impacts on photosynthesis, photorespiration and respiration. New Phytol. 2018, 221, 32-49. [CrossRef]

57. Lawlor, D.W. Limitation to Photosynthesis in Water-stressed Leaves: Stomata vs. Metabolism and the Role of ATP. Ann. Bot. 2002, 89, 871-885. [CrossRef] 
58. Gaire, N.P.; Koirala, M.; Bhuju, D.R.; Carrer, M. Site- and species-specific treeline responses to climatic variability in eastern Nepal Himalaya. Dendrochronologia 2017, 41, 44-56. [CrossRef]

59. Guo, M.; Zhang, Y.; Liu, S.; Gu, F.; Wang, X.; Li, Z.; Shi, C.; Fan, Z. Divergent growth between spruce and fir at alpine treelines on the east edge of the Tibetan Plateau in response to recent climate warming. Agric. For. Meteorol. 2019, 276-277, 107631. [CrossRef]

60. Hartl-Meier, C.; Dittmar, C.; Zang, C.; Rothe, A. Mountain forest growth response to climate change in the Northern Limestone Alps. Trees 2014, 28, 819-829. [CrossRef]

61. Green, T.H.; Mitchell, R.J. Effects of nitrogen on the response of loblolly pine to water stress I. Photosynthesis and stomatal conductance. New Phytol. 1992, 122, 627-633. [CrossRef]

62. Xu, J.; Lu, J.; Bao, F.; Evans, R.; Downes, G.; Huang, R.; Zhao, Y. Cellulose microfibril angle variation in Picea crassifolia tree rings improves climate signals on the Tibetan plateau. Trees 2012, 26, 1007-1016. [CrossRef]

63. Fonti, P.; Jansen, S. Xylem plasticity in response to climate. New Phytol. 2012, 195, 734-736. [CrossRef]

64. Janssen, E.; Kint, V.; Bontemps, J.-D.; Özkan, K.; Mert, A.; Köse, N.; Icel, B.; Muys, B. Recent growth trends of black pine (Pinus nigraJF Arnold) in the eastern mediterranean. For. Ecol. Manag. 2018, 412, 21-28. [CrossRef]

65. Cao, J.; Zhao, B.; Gao, L.; Li, J.; Li, Z.; Zhao, X. Increasing temperature sensitivity caused by climate warming, evidence from Northeastern China. Dendrochronologia 2018, 51, 101-111. [CrossRef]

66. Palombo, C.; Battipaglia, G.; Cherubini, P.; Chirici, G.; Garfi, V.; Lasserre, B.; Lombardi, F.; Marchetti, M.; Tognetti, R. Warmingrelated growth responses at the southern limit distribution of mountain pine (Pinus mugo Turra subsp. mugo). J. Veg. Sci. 2013, 25, 571-583. [CrossRef]

67. Zhang, Z. Tree-rings, a key ecological indicator of environment and climate change. Ecol. Indic. 2015, 51, 107-116. [CrossRef]

68. Zhang, L.; Li, S.; Hong, Y.; Zeng, X.; Liu, X. Changes in the radial growth of Picea crassifolia and its driving factors in the mid-western Qilian Mountains, Northwest China since 1851 C.E. Dendrochronologia 2020, 61, 125707. [CrossRef]

69. Gram, W.K.; Sork, V.L. Association between Environmental and Genetic Heterogeneity in Forest Tree Populations. Ecology 2001, 82, 2012. [CrossRef]

70. Randin, C.F.; Engler, R.; Normand, S.; Zappa, M.; Zimmermann, N.E.; Pearman, P.B.; Vittoz, P.; Thuiller, W.; Guisan, A. Climate change and plant distribution: Local models predict high-elevation persistence. Glob. Chang. Biol. 2009, 15, 1557-1569. [CrossRef]

71. Song, W.; Mu, C.; Zhang, Y.; Zhang, X.; Li, Z.; Zhao, H.; Wang, X. Moisture-driven changes in the sensitivity of the radial growth of Picea crassifolia to temperature, northeastern Tibetan Plateau. Dendrochronologia 2020, 64, 125761. [CrossRef]

72. Housset, J.M.; Nadeau, S.; Isabel, N.; Depardieu, C.; Duchesne, I.; Lenz, P.; Girardin, M.P. Tree rings provide a new class of phenotypes for genetic associations that foster insights into adaptation of conifers to climate change. New Phytol. 2018, 218, 630-645. [CrossRef]

73. Smith, N.G.; Dukes, J.S. Short-term acclimation to warmer temperatures accelerates leaf carbon exchange processes across plant types. Glob. Chang. Biol. 2017, 23, 4840-4853. [CrossRef]

74. Jacoby, G.C.; D'Arrigo, R.D. Tree ring width and density evidence of climatic and potential forest change in Alaska. Glob. Biogeochem. Cycles 1995, 9, 227-234. [CrossRef]

75. Kramer, P. Physiology of Woody Plants; Elsevier: Amsterdam, The Netherlands, 2012.

76. Massetti, E.; Mendelsohn, R. Temperature thresholds and the effect of warming on American farmland value. Clim. Chang. 2020, 161, 601-615. [CrossRef]

77. Fajardo, A.; Gazol, A.; Mayr, C.; Camarero, J.J. Recent decadal drought reverts warming-triggered growth enhancement in contrasting climates in the southern Andes tree line. J. Biogeogr. 2019. [CrossRef]

78. Nagavciuc, V.; Kern, Z.; Perşoiu, A.; Kesjár, D.; Popa, I. Aerial decay influence on the stable oxygen and carbon isotope ratios in tree ring cellulose. Dendrochronologia 2018, 49, 110-117. [CrossRef]

79. Darenova, E.; Acosta, M.; Pokorny, R.; Pavelka, M. Variability in temperature dependence of stem CO2 efflux from Norway spruce trees. Tree Physiol. 2018, 38, 1333-1344. [CrossRef] [PubMed]

80. Wang, B.; Chen, T.; Li, C.; Xu, G.; Wu, G.; Liu, G. Management. Radial growth of Qinghai spruce (Picea crassifolia Kom.) and its leading influencing climate factor varied along a moisture gradient. For. Ecol. Manag. 2020, 476, 118474. [CrossRef]

81. Choat, B.; Jansen, S.; Brodribb, T.; Cochard, H.; Delzon, S.; Bhaskar, R.; Bucci, S.J.; Feild, T.S.; Gleason, S.M.; Hacke, U.; et al. Global convergence in the vulnerability of forests to drought. Nat. Cell Biol. 2012, 491, 752-755. [CrossRef]

82. Zhou, H.; Sun, Y.; Shan, G.; Grantz, D.; Cheng, Q.; Lammers, P.S.; Damerow, L.; Wen, B.; Xue, X.; Chen, B.J.A.; et al. In situ measurement of stem water content and diurnal storage of an apricot tree with a high frequency inner fringing dielectric sensor. Agr. For. Meteorol. 2018, 250, 35-46. [CrossRef]

83. Ma, L.; Wu, J.; Abuduwaili, J. Climate and environmental changes over the past 150 years inferred from the sediments of Chaiwopu Lake, central Tianshan Mountains, northwest China. Acta Diabetol. 2012, 102, 959-967. [CrossRef]

84. Jiao, L.; Jiang, Y.; Wang, M.; Zhang, W.; Zhang, Y. Age-Effect Radial Growth Responses of Picea schrenkiana to Climate Change in the Eastern Tianshan Mountains, Northwest China. Forests 2017, 8, 294. [CrossRef] 